\title{
Plasma FSH, LH, the positive feedback of oestrogen, ovulation and luteal function in the ewe given bromocriptine to suppress prolactin during seasonal anoestrus
}

\author{
R. B. Land, W. R. Carr, A. S. McNeilly* and R. D. Preece \\ A.R.C. Animal Breeding Research Organisation, West Mains Road, Edinburgh EH9 3JQ; and \\ ${ }^{*}$ M.R.C. Unit of Reproductive Biology, 37 Chalmers Street, Edinburgh EH3 9EW, U.K.
}

\begin{abstract}
Summary. The effects of pharmacological reduction of the high plasma prolactin concentration typical of seasonal anoestrus in sheep were assessed with respect to positive feedback of oestrogen on $\mathrm{LH}$ release, ovulation, and progesterone secretion. Treatment of 16 Scottish Blackface ewes with $1 \mathrm{mg}$ bromocriptine, i.m. twice daily for 12 days, reduced prolactin concentrations in peripheral plasma from $64 \pm 10$ $\mathrm{ng} / \mathrm{ml}$ before treatment to $<4 \mathrm{ng} / \mathrm{ml}$. This treatment had no effect on the proportion of ewes discharging $\mathrm{LH}$ and $\mathrm{FSH}$ in response to $12.5 \mu \mathrm{g}$ oestradiol benzoate $(3 / 8$ before compared with $5 / 16$ during treatment) or the proportion of ewes ovulating in response to oestrogen treatment. Plasma progesterone concentrations remained low even in ovulating ewes.

It is concluded that treatment with bromocriptine alone is unlikely to restore oestrous cycles to ewes in seasonal anoestrus.
\end{abstract}

\section{Introduction}

Seasonal anoestrus in sheep has been postulated to arise in part from a reduced sensitivity of the positive feedback response to oestrogen (Land, Wheeler \& Carr, 1976). Since hyperprolactinaemia has also been reported to block the oestrogen-induced release of LH (Kann, Martinet \& Schirar, 1978), and hyperprolactinaemia is a characteristic of anoestrous sheep (Walton, McNeilly, McNeilly \& Cunningham, 1977), we have investigated the effects of reducing the prolactin concentrations in sheep during anoestrus with the dopamine agonist, bromocriptine.

\section{Materials and Methods}

Animals and experiments

The ewes were 4-year-old Scottish Blackface. The 16 animals were maintained outdoors at pasture under natural lighting at the A.B.R.O. Dryden Field Laboratory and in April 1977 a raddled vasectomized ram was introduced to check that they were anoestrous.

Reproductive activity was assessed by measuring the tonic concentrations of folliclestimulating hormone (FSH) and luteinizing hormone (LH) in peripheral plasma, and their response to an injection of oestradiol benzoate. The occurrence of oestrus, the incidence of 
ovulation, and progesterone production by any corpora lutea were also recorded. The oestrogen-induced release of $\mathrm{LH}$ was assessed in only 8 of the ewes before treatment with bromocriptine so that the effects of a reduction in the concentration of prolactin could be separated from possible effects of oestrogen.

Bromocriptine (CB 154: Sandoz Ltd) was used to suppress the release of prolactin; $1 \mathrm{mg}$ was given twice daily i.m. at $08: 30$ and 22:30 h for 12 days (Days $0-11$ inclusive), each dose being made up by diluting aliquots from a stock solution of CB 154 in $70 \%$ ethanol with sterile saline $(9 \mathrm{~g} \mathrm{NaCl} / 1)$ acidified with tartaric acid.

\section{Tonic concentrations of gonadotrophins in peripheral plasma}

Half of the ewes (Group A) were chosen at random and bled at 20-min intervals from 09:00 to $17: 00 \mathrm{~h}$ on Day -4 before the start of bromocriptine treatment on Day 0 . Blood was collected via an indwelling cannula placed in the jugular vein the previous day, and FSH, $\mathbf{L H}$ and prolactin were assayed in the plasma. This procedure was repeated in the same 8 ewes on Day 9. Comparisons of the hormone values on the 2 occasions were based on analysis of variance.

In 1 of these 8 sheep the concentration of $\mathrm{LH}$ on Day -4 reached $140 \mathrm{ng} / \mathrm{ml}$ on one occasion and the overall pattern was typical of a preovulatory discharge of LH. This animal was therefore excluded from the comparison of basal levels before and during bromocriptine treatment.

\section{Oestrogen-induced release of gonadotrophins}

The positive feedback response to oestrogen was tested in the other 8 ewes (Group B) which were injected $\mathrm{i} . \mathrm{m}$. with $12.5 \mu \mathrm{g}$ oestradiol benzoate B.P. (Intervet) made up to $2 \mathrm{ml}$ with ethyl oleate at 11:00 h on Day -4 . They were bled at $0.5,1$ and $1.5 \mathrm{~h}$ before and every $2 \mathrm{~h}$ from 1 to $29 \mathrm{~h}$ after the oestradiol injection. Blood was collected in evacuated heparinized tubes by repeated jugular venepuncture and FSH and LH were assayed in the plasma. The same oestrogen stimulation test was conducted in all 16 ewes on Day 10.

The dose of oestradiol benzoate was chosen after a small trial in which anoestrous Blackface ewes were treated with 6.25 (4 animals), 12.5 (4 animals), 25 (4 animals) or 50 ( 3 animals) $\mu \mathrm{g}$ oestradiol benzoate. An LH response was obtained in 0, 1, 3 and 3 animals respectively, and $12.5 \mu \mathrm{g}$ was therefore considered to be a suitable test dose for detecting any increase in hypothalamic sensitivity after bromocriptine treatment.

The criterion of effective positive feedback was related to comparison with the mean \pm s.e. values of tonic concentrations of FSH $(230 \pm 50 \mathrm{ng} / \mathrm{ml})$ and $\mathrm{LH}(1.5 \pm 2.1 \mathrm{ng} / \mathrm{ml})$. Using 3 standard deviations as a rigorous test of a deviation, this gave a criterion of 1.5 and 5 times the tonic concentration of FSH and $\mathrm{LH}$ respectively.

Ovulation. Both ovaries of all ewes were examined at laparoscopy on Days 1 and 17. The presence of a fresh (red) corpus luteum was taken as evidence of a recent ovulation. The concentration of progesterone was measured in blood samples collected daily on Days 12-18 as an index of the secretory activity of any corpora lutea.

Oestrus. The occurrence of oestrus was checked daily throughout the study by continuous teasing with vasectomized rams (apart from periods of blood sampling or surgery).

Prolactin concentrations. These were measured in samples collected daily on Days 0-11 at approximately 08:30 h, just before the next injection of bromocriptine. The mean \pm s.e.m. concentration declined from $63.8 \pm 10.2 \mathrm{ng}$ prolactin $/ \mathrm{ml}$ on Day 0 to $3.9 \pm 0.4 \mathrm{ng} / \mathrm{ml}$ the following morning. Thereafter mean concentrations did not exceed $2.8 \mathrm{ng} / \mathrm{ml}$, i.e. approximately $5 \%$ of normal, while bromocriptine treatment continued. 


\section{Hormone assays}

Plasma was stored at $-20^{\circ} \mathrm{C}$ until assayed.

$L H$ was measured by the double-antibody method of Carr \& Land (1975). The rabbit ovine LH antiserum validated for specificity and sensitivity by Martensz, Baird, Scaramuzzi \& Van Look (1976) and a purified ovine LH for labelling (M4; Jutisz \& Courte, 1968) were used in the assay and the results were computed by the A.B.R.O. Radioimmunoassay Program package based on the method of Rodbard \& Lewald (1970). NIH-LH-S18 was used as the standard. The minimum detectable dose was $0.3 \mathrm{ng} / \mathrm{ml}$ and the coefficient of variation among assays was 9.6\%.

FSH was measured in triplicate by the assay described by McNeilly, McNeilly, Walton \& Cunningham (1976). All samples were measured in one assay, the sensitivity of which was 16 $\mathrm{ng} / \mathrm{ml}$ (NIH-FSH-S10). The variation within the assay of 3 quality control sera (at 30, 55 and $80 \% \mathrm{~B} / \mathrm{Bo}$ ) was $9 \%$.

Prolactin was measured in duplicate as described by McNeilly \& Andrews (1974). All samples were measured in a single assay with a sensitivity of $0.05 \mathrm{ng} / \mathrm{ml}$ (NIH-P-56) and an intra-assay coefficient of variation of $8 \%$ for 3 quality control sera at 30,55 and $80 \% \mathrm{~B} / \mathrm{Bo}$.

Progesterone concentrations were measured in a single-antibody solid-phase assay, similar to that described by Dighe \& Hunter (1974), using a specific sheep antiprogesterone serum (Baird, Burger, Heavon-Jones \& Scaramuzzi, 1974). All standards were diluted with buffer containing charcoal-treated calf plasma before extraction, so that standards and unknowns contained the same amount of plasma. A control plasma sample from a ewe with a functional corpus luteum was included in the assay, and the potency estimate was $4.5 \mathrm{ng} / \mathrm{ml}(95 \%$ confidence limits $3.7-5.5 \mathrm{ng} / \mathrm{ml}$ ); previous experience indicated that ewes at mid-cycle or in early pregnancy had plasma progesterone levels of $>2 \mathrm{ng} / \mathrm{ml}$. The limit of sensitivity of the assay was $0.3 \mathrm{ng} / \mathrm{ml}$.

\section{Results}

\section{Tonic gonadotrophin concentrations}

FSH. The mean concentration of FSH was $230.8 \mathrm{ng} / \mathrm{ml}$ on Day -4 , before treatment, and $228.6 \mathrm{ng} / \mathrm{ml}$ during treatment. The means for individuals ranged from 162 to $310 \mathrm{ng} / \mathrm{ml}$ before treatment and from 172 to $373 \mathrm{ng} / \mathrm{ml}$ during treatment. The analysis of variance showed that there were real differences among animals $(P<0.001)$, and the repeatability computed as the intra-class correlation was 0.63 .

$L H$. Pulsatile release of $\mathrm{LH}$ occurred, the frequency decreasing from 1 peak $/ 5 \mathrm{~h}$ before treatment to 1 peak $/ 8 \mathrm{~h}$ during treatment, but the difference is not statistically significant.

As with FSH there was an approximately 2 -fold range among animals, but the probability of the variation arising by chance was less than $5 \%$ only when the data were transformed to logarithms to cope with the log normal distribution of $\mathrm{LH}$ resulting from the pulsatile nature of its release. The highest and lowest animal means were 2.2 and $1.1 \mathrm{ng} / \mathrm{ml}$ before treatment and 2.9 and $0.4 \mathrm{ng} / \mathrm{ml}$ during treatment. The repeatability of the concentration was $3 \%$ based on the untransformed data, and $12 \%$ based on the transformed data. The arithmetic mean plasma $\mathrm{LH}$ concentration was $1.57 \mathrm{ng} / \mathrm{ml}$ before and $1.51 \mathrm{ng} / \mathrm{ml}$ during treatment, indicating an overall lack of effect of bromocriptine treatment on $\mathrm{LH}$ concentrations.

\section{Positive feedback}

As shown in Table 1, 3 of the 8 ewes treated with oestradiol on Day -4 discharged both FSH and $\mathrm{LH}$; the rise in concentration of FSH was $2 \mathrm{~h}$ later than that of $\mathrm{LH}$ in all 3 ewes. Of the 16 animals treated with oestradiol on Day 10, LH was released by 5 ( 2 from Group A, 3 from 
Group B). These 5 ewes also released FSH, which was again $2 \mathrm{~h}$ after the rise in $\mathrm{LH}$ concentration. Bromocriptine treatment did not therefore affect the proportion of animals releasing $\mathrm{LH}$ or FSH in response to oestradiol.

Ovulation. Oestradiol treatment was followed by ovulation in 3 of the 8 Group B animals tested on Day -4 and in 2 of the 8 Group A ewes tested on Day 10. The Group A ewe that showed a preovulatory-type LH surge on Day -4 had ovulated by the time of laparoscopy on Day 1. In none of the 16 animals was the plasma progesterone concentration on Days 12-18 above $0.7 \mathrm{ng} / \mathrm{ml}$ and it was mostly $<0.3 \mathrm{ng} / \mathrm{ml}$, indicating that the corpora lutea formed in response to oestradiol treatment were not functional. A rise in $\mathrm{LH}$ concentration was not detected in 2 ewes which ovulated after the oestrogen injection (Table 1). In 1 of the ewes the concentration was rising in the last 2 samples collected, but it did not do so sufficiently to meet the criteria set for positive feedback. There was no indication of an LH discharge for the other animal. Two of the 3 sheep that ovulated after the first oestradiol injection also released LH after the second oestradiol injection, further evidence that the corpora lutea were non-functional. However, neither ewe ovulated in response to the second injection. Treatment with bromocriptine did not therefore increase the proportion of ewes ovulating after injection of oestradiol benzoate.

Table 1. Summary of the effects of bromocriptine on the oestrogen-induced LH discharge and the incidence of ovulation in Blackface ewes during anoestrus

\begin{tabular}{cccccc}
\hline & $\begin{array}{c}\text { Total } \\
\text { no. of } \\
\text { ewes }\end{array}$ & $\begin{array}{c}\text { LH response } \\
\text { to oestradiol } \\
\text { on Day -4 }\end{array}$ & $\begin{array}{c}\text { No. with } \\
\text { fresh CL } \\
\text { on Day 1 }\end{array}$ & $\begin{array}{c}\text { No. with (+) and without } \\
(-) \text { LH response to } \\
\text { oestradiol on Day 10 }\end{array}$ & $\begin{array}{c}\text { No. with } \\
\text { fresh CL } \\
\text { on Day 17 }\end{array}$ \\
\hline $\begin{array}{c}\text { Oestradiol on Day 10 } \\
\text { only (Group A) }\end{array}$ & 8 & - & 1 & $\begin{array}{c}2+ \\
6-\end{array}$ & 1 \\
\hline $\begin{array}{l}\text { Oestradiol on Days -4 } \\
\text { and 10 (Group B) }\end{array}$ & 8 & $3+$ & 2 & $1+$ & 0 \\
& & $5-$ & 1 & $2-$ & 0 \\
& & & & $3-$ & 0 \\
\hline
\end{tabular}

\section{Discussion}

The principal object of the experiment was to examine the extent to which a reduction in the concentration of prolactin in peripheral plasma by treatment with bromocriptine might facilitate the restoration of reproductive function in anoestrous ewes. Bromocriptine treatment did reduce the concentration of prolactin dramatically but this did not lead to a detectable increase in sensitivity to positive feedback, and there was no increase in the number of animals ovulating. Small changes in the proportion of ewes discharging LH in response to the injection of $12.5 \mu \mathrm{g}$ oestradiol could not have been detected in an experiment of this size, and with the impossibility of testing the sensitivity of intact cyclic ewes in this way the purported effect and hence the change to be detected cannot be given. Land et al. (1976) found that the number of ovariectomized Finnish Landrace ewes that discharged LH often varied from 4 of 12 at the time of anoestrus (the same as in the total of untreated females in the present study) to 12 of 12 in November, but no such increase was obtained in the present experiment. The results therefore do not confirm the implication of the observation by Kann et al. (1978) that TRH-induced hyperprolactinaemia reduced sensitivity of ovariectomized ewes to positive feedback during the breeding season, and that bromocriptine, at a dose which reduced the concentration of prolactin in the plasma of suckling ewes, increased their sensitivity to positive feedback. Despite this demonstration that high prolactin levels suppress positive feedback, the presence of high 
prolactin concentrations during anoestrus, the ability of bromocriptine to suppress these concentrations, and although positive feedback may be reduced (Land et al., 1976) and negative feedback may be increased (Legan \& Karsch, 1979) during seasonal anoestrus, the present results indicate that insensitive positive feedback arises for reasons over and above hyperprolactinaemia. Furthermore, as reported by Haresign, Foster, Haynes, Crighton \& Lamming (1975) and by McNeilly \& Land (1979) for LH-RH-induced corpora lutea, the corpora lutea formed did not secrete progesterone. It may therefore be concluded from the present short-term, acute tests that unless hyperprolactinaemia has a long-term chronic effect, treatment with bromocriptine alone is unlikely to lead to a resumption of oestrous cycles. It must, however, be borne in mind that bromocriptine may have effects on reproduction beyond the suppression of prolactin release; for example, McNeilly \& Land (1979) report a reduction in the LH-RH-induced release of gonadotrophins. It is also evident that individuals differ markedly; the concentration of FSH and of LH both varied 2-fold although all animals were of the same breed and all were anoestrous.

Legan \& Karsch (1979) have questioned the role of changes in positive feedback in the control of anoestrus in the ewe, and propose that seasonal changes are regulated by variation in the sensitivity of the negative feedback of oestradiol on tonic LH secretion alone. Increased sensitivity during anoestrus prevents the initiation of the LH cascade which normally culminates in the preovulatory discharge. Legan \& Karsch (1979) suggest that the seasonal changes in positive feedback found in long-term ovariectomized ewes by Land et al. (1976) may only have been detected as a result of fundamental changes in the response of the hypothalamus to oestrogen following the prolonged absence of gonadal steroids, and as such do not constitute evidence for steroid-independent change in hypothalamic activity. The magnitude of any such effect is not, however, large: 4 of 12 ewes treated with $12.5 \mu \mathrm{g}$ oestradiol for the first time responded in the present experiment compared to 8 of 12 long-term ovariectomized ewes which responded to $50 \mu \mathrm{g}$ in the earlier experiment. An increase in sensitivity to negative feedback and a decrease in sensitivity to positive feedback may not be alternatives but rather reflections of underlying seasonal changes in CNS activity and hence may both be characteristic of seasonal anoestrus. Other seasonal changes can be demonstrated. For example, prostaglandin F- $2 \alpha$ leads to the release of $\mathrm{LH}$ during the breeding season but not during anoestrus (Roberts, Carlson \& McCracken, 1976), and prolactin concentrations rise spectacularly during anoestrus (Ravault, 1976). Both of these responses may reflect a general change in spontaneous hypothalamic activity rather than a specific effect dependent upon steroids as discussed by Land \& Carr (1979). Given that a decrease in hypothalamic activity would lead to both stronger negative feedback and weaker positive feedback and the known differences in feedback sensitivity and seasonality among breeds of sheep, the relative contributions of these two secondary changes to the actual cessation and resumption of cyclicity may vary among sheep and among environments.

We thank Miss M. Fordyce for surgical and Mr G. Baxter, Miss N. Anderson, Miss B. Archiband and Mrs M. Swaney for laboratory assistance, and the NIAMDD and Dr M. Jutisz for purified preparations. We are grateful to Professor R. V. Short for constructive advice, and to Sandoz Ltd for the gift of bromocriptine.

\section{References}

Baird, D.T., Burger, P.E., Heavon-Jones, G.D. \& Scaramuzzi, R.J. (1974) The site of secretion of androstenedione in non-pregnant women. $J$. Endocr. 63, 201-212.

Carr, W.R. \& Land, R.B. (1975) Plasma luteinizing hormone levels and testis diameters of ram lambs of different breeds. J. Reprod. Fert. 42, 325-333.

Dighe, K.K. \& Hunter, W.M. (1974) A solid phase radioimmunoassay for plasma progesterone. Biochem. J. 143, 219-231. 
Haresign, W., Foster, J.P., Haynes, N.B., Crighton, D.B. \& Lamming, G.E. (1975) Progesterone levels following treatment of seasonally anoestrous ewes with synthetic luteinizing hormone-release hormone. $J$. Reprod. Fert. 43, 269-279.

Jutisz, M. \& Courte, C. (1968) Hormone luteinisante (LH) du mouton. 1. Obtention a L'etat apparament homogene. Etude physio-chimique et biologique. Gen. comp. Endocr. 11, 562-574.

Kann, G., Martinet, J. \& Schirar, A. (1978) Hypothalamic-pituitary control during lactation in sheep. In Control of Ovulation, pp. 319-333. Eds D. B. Crighton, N. B. Hayes, G. R. Foxcroft \& G. E. Lamming. Butterworth, London.

Land, R.B. \& Carr, W.R. (1979) Reproduction in domestic mammals. In Genetic Variation in Hor mone Systems, vol. 1, pp. 89-112. Ed. J. G. M. Shire. CRC Press, Miami.

Land, R.B., Wheeler, A.G. \& Carr, W.R. (1976) Seasonal variation in the oestrogen induced $\mathrm{LH}$ discharge of ovariectomized Finnish Landrace and Scottish Blackface Ewes. Anns Biol. anim. Biochim. Biophys. 16, 521-528.

Legan, S.J. \& Karsch, F.J. (1979) Neuroendocrine regulation of the estrous cycle and seasonal breeding in the ewe. Biol. Reprod. 20, 74-85.

McNeilly, A.S. \& Andrews, P. (1974) Purification and characterization of caprine prolactin. J. Endocr. 60, 359-367.

McNeilly, A.S. \& Land, R.B. (1979) Effect of suppression of plasma prolactin on ovulation, plasma gonadotrophins and corpus luteum function in LH-RH-treated anoestrous ewes. J. Reprod. Fert. 56, 69-609.

McNeilly, J.R., MeNeilly, A.S., Walton, J.S. \& Cunningham, FJ. (1976) Development and application of a heterologous radioimmunoassay for ovine follicle-stimulating hormone. J. Endocr. 70, 69-79.

Martensz, N.D., Baird, D.T., Scaramuzzi, F.J. \& Van Look, P.F.A. (1976) Androstenedione and the control of luteinizing hormone in the ewe during anoestrus. J. Endocr. 69, 227-237.

Ravault, J.P. (1976) Prolactin in the ram: seasonal variations in the concentration of blood plasma from birth until three years old. Acta endocr., Copenh. 83, $720-725$

Roberts, J.S., Carlson, J.C. \& McCracken, J.A. (1976) Prostaglandin F $2 \alpha$ production by the brain and its role in LH secretion. Adv. Prostaglandin and Thromboxane Res. 2, 609-619.

Rodbard, D. \& Lewald, J.G. (1970) Computer analysis of radioligand assay and radioimmunoassay data. Acta endocr., Copenh., Suppl. 147, 79-103.

Walton, J.S., McNeilly, J.R., MeNeilly, A.S. \& Cunningham, F.J. (1977) Changes in concentrations of follicle stimulating hormone, luteinizing hormone, prolactin and progesterone in the plasma of ewes during the transition from anoestrus to breeding activity. J. Endocr. 75, 127-136.

Received 12 September 1979 